Edwards and Major F. B. Halford; Honorary Treasurer, C. F. Uwins ; Honorary Librarian, J. E. Hodggon; Secretary, Captain J. Laurence Pritchard.

\section{Lady Tata Memorial Fund: Awards}

THE following awards for research in blood diseases, with special reference to leukæmia, to be conducted in the places shown during the academic year beginning on October 1, have been made by the Lady Tata Memorial Fund: Grants for research expenses and assistance, Prof. J. Bichel (Aarhus), Dr. G. Discombe (London), Dr. Astrid Fagraeus and Dr. Bo Thorell (Stockholm), Dr. N. G. Harboe (Copenhagen), Dr. E. Kelemen (Szeged), Prof. C. Oberling (Paris), Dr. Edith Paterson (Manchester), and Dr. G. Schallock (Münster); Scholarships, Dr. P. Atanasiu (Paris) and Dr. H. P. L. Febvre (Paris).

\section{Exhibition Studentship Awards}

THe Royal Commission for the Exhibition of 185 has announced the award of senior studentships for 1950 to the following, for research to be carried out at the places stated: Dr. B. R. Brown (organic chemistry at the University of Cambridge); $\mathbf{A}$. Jobling (physical chemistry at the Imperial College of Science and Technology, London); Miss J. C Mott (animal physiology at the University of Oxford); and Dr. K. Robinson (erystallography at the Univer. sity of Cambridge). The awards are of the value of f600-650 a year and are ordinarily tenable for two years.

\section{Vacation Course in Meteorology}

A SHORT vacation course in observational and synoptic meteorology has been arranged by the Council for the Promotion of Field Studies, in co-operation with the Royal Meteorological Society, and will take place at Malham Tarn Fields Centre, near Settle, Yorkshire, during September 6-13. Malham Tarn is situated on the limestone uplands at the head of Airedale in the Yorkshire Pennines, at a height of $1,229 \mathrm{ft}$. and two miles north of the village of Malham. The geology of the area is dominated by the Craven Fault system, which extends, with a downthrow to the south from near Kirkby Lonsdale in the west through Ingleton, Settle and Malham to Nidderdale in the east, and the fault-line scarp is revealed in the magnificent scars of Giggleswick, Malham Cove and Gordale. Evidence of glaciation is apparent everywhere as moraines, drift, glacial tarns and erratic blocks, and the 'karst' phenomena of limestone country such as underground drainage, sundry valleys, swallow holes, potholes, caves and limestone pavements can be seen. The vegetation offers remarkable opportunities for studying the ecology of moorlands, bogs, mountains and limestone pavements. The Tarn is a typical calcareous water with a rich rooted vegetation showing no special feature due to altitude except the bareness of the actual shoreline; it is nowhere deeper than $14 \mathrm{ft}$. The 'Moss' at the west end of the Tarn has old raised bog, fen carr, reed swamp and marsh area, and here are many interesting species of plants. The course, which is under the direction of James Paton, lecturer in meteorology in the University of Edinburgh, is designed for school pupils in sixth forms, students, teachers and amateur observers, as well as professional workers who make use of micro- and macro-climatological studies; an elementary knowledge of physics will be assumed. The inclusive cost is five guineas.
Forms of application (to be returned as soon as possible) can be obtained from the Director, Council for the Promotion of Field Studies, 10 Exhibition Road, London, S.W.7.

\section{Announcements}

THe Rev. P. Teilhard de Chardin, correspondaint of the Mineralogy Section of the Paris Academy of Sciences and director of laboratories at the École des Hautes Etudes, has been elected non-resident member of the Paris Academy of Sciences in succession to the late M. René Maire.

Mr. L. H. C. TIPPEtT, head of the Mechanical Processing Division of the British Cotton Industry Research Association, Shirley Institute, Manchester, has been awarded the Warner Medal of the Textile Institute in recognition of his outstanding work in textile science and technology, particularly work published in the Journal of the Institute. Mr. Tippett will be the fifteenth recipient of the Warner Medal since its inauguration in 1930 to perpetuate the memory of Sir Frank Warner, for many years an enthusiastic worker for the Institute, and president during 1918-19.

Mr. R. E. BURnetT has been appointed by Marconi's Wireless Telegraph Co., Ltd., to be manager of the Education Department and principal of the Marconi College, Chelmsford, Essex. Mr. Burnett, who is thirty-five years of age, will be responsible, in addition to his other duties, for the recruitment of technical personnel at Marconi's in collaboration with the Central Personnel Services of the English Electric Group. Mr. Bumett was head of the mathematics, physics and electrical engineering side of the Technical and Scientific Register of the Ministry of Labour.

THE Institute of Industrial Administration has recently awarded the travelling scholarship for 1950 , tenable in the United States, to Mr. H. Aishen, of the Merseyside Centre of the Institution. This annual scholarship is for study in the United States for a minimum period of ten weeks. Mr. Aishen is secretary - chief accountant and financial member of the Management Committee of the British Extracting Co., Ltd., and Lever's Cattle Foods, Ltd., both associates of Lever Bros. and Unilever, Ltd. $\mathrm{He}$ was awarded the Wilson Medal of the Institute in 1945.

Tнe Giornate Mediche Internazionali will be held in Verona during July 20-30. This year the scope of the congress has been extended, and a certain number of distinguished non-Italian medical men will contribute to the discussions. All communications regarding the congress should be addressed to Prof. L. Barchi, Giornate Mediche Internazionali, Pescheria Vecchia 6, Verona.

The third symposium on plasticity to be held in Brown University will take place during September 8-9, under the auspices of the Graduate Division of Applied Mathematics. The two topics for discussion will be stress-strain relations, and problems and methods in the analysis of structures and continuous media. The symposium is open to all interested in these fields, and experts both from the United States and from other countries will present papers on recent experimental and analytical research. Further details can be obtained from Prof. D. C. Drucker, Brown University, Providence 12, Rhode Island. 